\title{
TEACHING ENGLISH TENSES THROUGH POPULAR MOVIES - A CASE STUDY
}

Abstract: The paper deals with teaching the Present Perfect and Present Perfect Continuous by using the scripts and clips from the blockbuster saga The Avengers. The relevance of this topic lies in the fact that grammar is traditionally considered a difficult aspect of learning a language. If we start including popular culture into the classroom and try to teach the grammar this way, we might make it easier for them to identify with the content that is traditionally considered uninteresting and difficult to master. The aim is to see whether teaching grammar through popular culture, set within a top-down approach of focusing on meaning (uses) rather than form, could prove to be effective. Another aim is to ascertain how 10 students (out of 20) from the experimental group would respond to this modern approach. A two-group experimental design was used and accompanied by a descriptive and statistical analysis. The testing technique was applied. The control group better mastered the form of the tenses, while the experimental group better mastered the meaning (uses) of the tenses. The latter group found the class more motivating. Teachers could consider teaching English grammar this way. However, to achieve better results, it would be advisable to focus on the form of the tenses as well.

Key words: popular culture, motivation, top-down approach, functional grammar approach.

\section{INTRODUCTION}

Grammar has been traditionally considered the least interesting aspect of learning a language. The students tend to lose interest and motivation to listen to what the teacher explainssimply because they are bombarded by the

\footnotetext{
*Srđan Gajdoš, srdjangajdos@gmail.com
} 
sets of rules which mastery seems impossible to achieve. Grammatical structures are provided to them in the textbooks, which often bear no relation to what they would consider relatable. Jean and Simard (2011) discussed the research results of their questionnaire and concluded (based on a sample of 2,361 respondents) that the majority of students and teachers found grammar instructions necessary but uninteresting. Ozkan (2015) criticised the lack of authenticity in traditional textbooks. Based on his research conducted on Turkish students, he concluded that using personalized texts for teaching grammar could make the process meaningful, since the form of grammatical units could be related to their actual meanings. Kinet and Meunier (2017) conducted the research on students by using technology as opposed to simply using a pen and paper, and found that the results in a delayed test were higher in the experimental group, concluding that the technology could have a positive impact on the students' acquisition of grammar. The students confirmed that they preferred the experimental classes. The actual question is whether the content found within more entertaining and meaningful contexts could itself become perceived as more understandable and easy to learn.

The content and the manner of teaching need to be tailored in order to meet the changing trends of society. Looking at today's trends among teenagers, it is apparent that they are heavily immersed in the world of popular culture, and that a significant number of them are familiar with the plots of blockbuster movies. According to Statista (2019), close to $30 \%$ of cinema viewers in the UK in 2014 were from 15 to 24 years old. They have pointed out that this age group is also the most active one in the USA. This content can be the focal point of class or simply a complement to it. The 
richness of the discourse that can be found in the scripts of movie sagas is sufficient to provide the teachers with authentic material.

\section{THEORETICAL BACKGROUND}

\section{Popular culture and motivation}

Cheung (2001) suggests that teachers need to be aware of how the students live and what they enjoy. Teachers should tailor their classes by taking into account what the students prefer in order to feel a part of what is being discussed. Doing popular culture in the classroom makes them feel relaxed and eager to learn. Harmer (1991) posits that teaching a language is simply insufficient, and that it needs to be accompanied by something the students will relate to because they are familiar with it. Gale (2012) discusses the findings of his research and concludes that many students studying Japanese are taken in by the appeal of anime, which essentially determines their career path in life. Khan (2015) states that watching movies is a pastime of the students and should, therefore, be brought into the classroom. Before the movie is watched, the teacher can provide the students with key vocabulary, or the students can discuss the characters they know from the movie. During the film, the teacher can check if the students understand the plot, and once it is finished, they can have discussion groups. The following case studies present the results regarding popular culture in the classroom and its correlation to motivation. Brown (2010) conducted the research on a sample of 80 university Japanese students in order to determine the efficiency of watching movies at class. Before watching the 10-minute movie segments, they were provided with key vocabulary which would be important for that particular clip. After watching it, they were told to provide a summary of the 
scene, which they gave in a written form. The next exercise implied making corrections to the movie script. Then they were told to order the events they were given according to the order they appeared in. They were also asked to answer the questions related to the scenes. The test results showed that culture specific words were not easy to learn. Ismaili (2013) conducted the research on a sample of 60 undergraduate students aged 18-25. Half of them were in the experimental group and taught using movies. The other half of them were taught conventionally. The key difference was that the experimental group watched a movie based on the two books. In the control group, the students were given lists of vocabulary important for the book. They were given pre-reading questions, while the post-reading questions came after the text. The students first answered true/false questions as a brainstorming activity. They also had to answer comprehension questions while watching 10 to 15 minute clips. Both the students and teachers expressed their satisfaction with the class. Kalra (2017) conducted the research on a sample of 90 Thai undergraduate students aged 19-22. The majority of the students stated that watching movies at class had a positive effect on the atmosphere and motivation. Close to $80 \%$ of them answered that they could learn vocabulary units easier since the units were provided in a context. They believed their speaking ability could be improved by watching movies, and that their overall enthusiasm and motivation was higher after taking a part. The teachers gave similar answers to the students, with close to $90 \%$ of them in favour of using movies at class.

Top-down vs. bottom-up approach

The paper at hand focuses on a setting which is immersed in popular culture, and which gravitates more towards understanding and relating to 
what is said than towards the form of the units. This approach is referred to as the top-down approach, which Using English (2019) defines as looking at language as a whole and giving priority to the meaning rather than to the form and the structure. Hyte (2016) adds that background knowledge can help to predict the meaning of the units being taught, which is essentially in line with teaching through popular culture due to its familiarity. In dealing with listening strategies, Henderson (2017) points out that examining the smaller units of a language first is what constitutes the bottom-up approach. The top-down approach is also referred to as the inductive approach, whereas the bottom-up approach is called the deductive approach. As Male (2018) points out, the advantage of the inductive approach is making the rules more meaningful and memorable. In addition, the mental effort implies greater cognitive depth and memorability, and there is a greater involvement. The inductive approach plays a central role in this research due to its greater suitability to the analysis of concrete examples. Kim (2007) conducted the research in the field of the two approaches on a sample of 90 Korean university students. The students of the experimental group were provided with textual examples. They were also expected to do exercises for their homework in order to follow the coursework. The texts and worksheets they got were supposed to encourage them to come up with the rules. Conversely, the students of the control group were explicitly presented with the rules. The test showed that the experimental group did better.

\section{The traditional approach $v$ s. the functional approach}

Although there are numerous teaching methods, the grammatical aspect seems to be universally recognised as no easy task. The functional 
approach focuses on how language works (teaching different parts of speech along with the rules), but not how it is used. Winch (2010) suggests that the traditional approach is still the most dominant one. The functional method implies teaching grammatical units through the context, after which the rules are defined. The meaning of the structures is the focus of the class rather than the form itself. Only after deriving of the meaning from the structure, the formal rules could be defined (Weebly, 2019). The context could serve as a means, not only to remember the structure through repetition, but rather as a situation that would facilitate memorising the meaning of the units based on the whole context in which it appears. Since the students have an emotional connection to what they are reading and watching, they can remember the constructions better. Long \& Doughty (2009) say that the traditional approach of learning, practicing, and presenting leads to a discrepancy in the theoretical knowledge which the students have of the grammar rules, and their actual ability to apply them in real situations. Byrd (2005) states that if grammar is presented in a context, the forms of certain structures are seen as representations of different meanings.

\section{METHODOLOGY}

\section{Research topic and hypotheses}

The aim of the paper is to establish whether using the movie scripts and clips from The Avengers saga to teach the Present Perfect and Present Perfect Continuous will prove effective. Since the different contexts/scenes should help the students to remember different uses of tenses, teaching will be done from a top-down approach by giving a priority to the meaning rather than the form. This will be conducted parallel to the control group, which 
will be taught by using the exercises from a chosen book, following the instructions from the teacher's book, and using the bottom-up approach. The first hypothesis is that the students from the experimental group will understand the meaning of tenses better if taught using a modern approach. The second hypothesis is that they will find the content more motivating.

\section{Participants}

The respondents of this research were 20 elementary and high school students aged 14 to 18 . They attended the intermediate (B1) course in a private language school in Novi Sad, Serbia in 2019. Thirteen of them were males, and the remaining seven were females. These 20 students were originally divided in three different groups, but they were merged into two groups (control and experimental) just for the purposes of this research. All the students did an entry test on the day they applied for the classes in this school. They were assigned to these three groups based on their level of knowledge and the time of availability. Duration of the classes they were attending twice a week was 90 minutes.

\section{Research Design}

This research was conducted through the testing technique. The two classes held with these two groups consisted of two parts. One part of the lesson was dedicated to grammatical exercises (45 minutes), while the following 20 minutes were allotted to an immediate test. The remaining 25 minutes were spent continuing the lesson, but this part was not taken into account. The control group (10 students) was taught grammatical structures from the third Unit according to the instructions from the teacher's book 
accompanying the course. The focus was on doing the exercises on page 37 of the New Opportunities Intermediate Student's Book. These exercises implied a theoretical part along with two texts that had to be completed with the Present Perfect Continuous of the verbs in the first text, and the same tense in combination with the Present Perfect in the other. The first text was a list of independent sentences that had to do with travelling. After being told about the uses of these two tenses, and how they were formed (a theoretical introduction), the students were expected to do the exercises.

The whole process of explaining the grammar and doing the exercises was exclusively linked to the rules and different uses, without going beyond this scope. There was no mention of any external context that the students would be able to relate to. The bottom-up (traditional) approach was utilised in teaching the grammar since the rules were first provided, followed by the body of examples. In the experimental group, the material and approach in which it was presented to the other ten students was significantly different. A collection of sentences was compiled from the film scripts of The Avengers saga (The Endgame, Infinity War and Guardians of the Galaxy), which was selected due to its world-wide popularity and appeal. It was impossible to find a text from the movie in which only these two tenses appeared, so independent sentences (situations) were the only option. There was no initial focus on explaining the form of the tenses. The focus was on encouraging the students to try to remember the situations and parts of the movie they appeared in, as well as who said the lines and whom they were addressed to. Then they played the same scenes from the movie in order to better contextualise the situations and get a holistic understanding of why such tenses were used. The students of both groups were given the same test. They 
were asked to complete 4 exercises, whereas the other section of the test was in the form of a questionnaire in which the students were asked about the nature of the class and whether they enjoyed it or not.

\section{Instrument}

A twenty-minute test was given to both groups after 45 minutes of class. The test consisted of two parts. The first part contained four exercises that dealt with the two tenses. The first exercise required from them to match the tense with different uses of the tenses. There were three sentences that matched with the list of rules. In this exercise, they were also asked to come up with additional examples that would illustrate the mentioned uses. The next exercises entailed putting the verbs in brackets into the Present Perfect (ten sentences). The following exercise implied putting ten verbs into the Present Perfect Continuous. The final exercise required from them to put the verbs into the right tense in ten sentences. After doing the linguistic section of the test, they moved on to answer the questions related to their personal preference of the nature of both classes. This section was done by providing an answer from 1 to 5 ( 1 being the weakest and 5 being the strongest degree of agreement with the statements), or giving an answer to an open-ended question. There were six questions in the questionnaire.

\section{Data collection procedure}

A two-group quasi-experimental quantitative method was used to collect the data. In addition to this, a short questionnaire was given to them by the end of class. On conducting the experiment with the control and experimental group, the data were analysed descriptively and statistically. 
The statistical data obtained through basic statistical (mathematical) operations were presented in Word tables, and these results were described and commented on. A comparison of the results was performed in light of the two groups.

In the control group, the students were first given the form of the two tenses at hand. This was written for them on the board. After this brief introduction, they were also presented the uses of these two tenses. The control group did the exercises from the textbook one by one. In the fifth exercise, the students were expected to write the missing verbs from the exercises on the previous page in the Present Perfect Tense. There were three such sentences. In the sixth exercise, there was a table which consisted of six sentences. The first three sentences were about the Present Perfect Continuous and Present Perfect Tenses. The seventh exercise required from the students to refer back to the previous two exercises and identify which of the three uses refer to which tense. In the next exercise, the students had to complete seven questions with the verb in the Present Perfect Continuous. In the eighth exercise, they were asked to speculate on the reasons why something was done in a certain way. The ninth exercise implied acting out dialogues by using the Present Perfect Continuous for the situations that the students were given. The students were expected to interact in a dialogue that was random and unfamiliar to them. The tenth exercise was short and required from the students to provide the appropriate tense for a certain situation. Also, they were asked what the appropriate questions would be if we wanted to ask about someone's success in a training programme. The last instance had to do with complaining about our garage. The final exercise required from them to provide the verbs in the correct tense of the two 
options. They were given a text about a traveller being interviewed. In the twelfth exercise, they were asked to provide personalised sentences in which they would use both tenses. It was evident that the only relatable content of the students in the control group was the last one, since it had to come from their own experience.

In the experimental group, the approach was different in a number of ways. The very beginning of class lacked the previous reference to the cartoon that the control group had. The first exercise focused on ten sentences that the students were supposed to fill in using the Present Perfect. Before writing the verbs in the form they were required to, they first saw parts of the movie where the characters actually verbalised the exact same sentences, one by one. Upon hearing the sentence, they wrote the verbs in the required form and were asked to identify the characters who said the particular sentences and to whom. Not only were they encouraged to recognise the characters, but also to think about the part of the movie where the sentences were said and what their implications were. The sentences were chosen from The Endgame, so that understanding of the units would be distinguished from the other tense (movie scenes). Once the sentences were analysed and checked one by one, the students were asked to draw their own conclusions regarding how the Present Perfect was used in these sentences. Prior to doing the exercises from the paper, the students were not instructed when and how the tense was used. In the next exercise, certain scenes were briefly summarised and prompts were provided to construct the continuation of those sentences, using the verb in the Present Perfect Tense. The identical process was repeated with the sentences containing the Present Perfect Continuous. On hearing the sentences uttered by the characters, the whole situations were 
discussed and the answers were written down. The sentences were taken from the Avengers: Infinity War and Guardians of the Galaxy. After doing these ten sentences, the rules about the formation of the tense were not defined, while the use of the tense was. The next exercise required from them to put the verbs of different movie scenes into the correct tense. They were not given a dialogue, but separate scenes. The final exercise asked them to come up with their own sentences as illustrations of the two tenses.

\section{RESULTS AND ANALYSIS}

The following passages deal with the test results of each group, along with the discussion of these results. The questions from the test (Appendix) have been provided with their answers and the analysis of the results. The test includes a final section in the form of a short questionnaire, which has been also presented and discussed.

\section{Test (control group)}

In the first exercise of the test, there were 90\% (Table 1) of correct answers. This high percentage may be due to the fact that the exercises done at class were effective i.e. the sentences were a clear illustration of what the two tenses could imply. Another reason for their success could be due to the fact that the focus at class was on the rules and theoretical aspect of the tenses. They were obviously well aware of what the tenses could denote. Some other uses of the Present Perfect were not included in the test since these additional uses were not intended to be covered at that class. The focus was on emphasising the completion of one tense and the incompletion and repetition of the other to make the story more straightforward. The exercise was identical to the one that they did at class, which might be another reason 
why it was done with great accuracy. The sentences that they additionally provided were done with the same rate of accuracy.

In the next task, they were expected to form sentences based on the prompts and use of the Present Perfect. This exercise was done extremely well (84\%), with five of them answering the questions without making a mistake. This implied that focusing first on teaching the form, and focusing more strictly on the rules resulted in achieving a very high score on the test in turn. The mistakes made with spelling of the Past Participle form were not taken into consideration. Rather, the focus was on writing the correct form of the auxiliary verbs. Only four students made mistakes with the auxiliary verbs by not using them in the right person or not writing the negative form of the verbs. The success can also be attributed to the relatively simple and short formation of this tense.

In the next task, the students were again expected to form sentences, but this time using the Present Perfect Continuous Tense. This exercise was done with even greater accuracy (86\%). Out of the total number of students, six of them did everything correctly. This could be explained by the fact that the formation of the tense itself was even easier than in the previous exercise. They did not have to be careful with the Past Participle because they simply added the inflection -ing. In some cases, the students made mistakes by putting the auxiliary verb in the incorrect person or omitting been, which was counted as a mistake.

In the next task, they were expected to choose the correct tense in the existing sentences. In comparison with the previous two exercises where the focus was simply on the form, the students had more difficulty choosing the 
correct tense (67\%). Naturally, it was logical that the nature of such an exercise was more demanding since both the form and the use had to be taken into account. However, there was still a noticeably stark discrepancy between the results obtained in the exercises that had to do with the form as opposed to those obtained in this one. The mistakes usually stemmed from not realising which tense to use. In cases where they recognised which tense would be appropriate, they did not make mistakes with the form. It appeared that the use of the tenses was not nearly as successfully mastered as the formation of the tenses. A possible explanation was that the uses were not fully mastered because they were provided within a forgettable context at class.

As far as the questionnaire was concerned, the students answered six questions, either in the form of sentences or by writing a number.

This set of questions served as a very valuable source of a feedback from the students themselves. The average number for the first question was 3 (Table 2), with only three students answering with 4 or 5 . This gave the impression that the majority of them did not think too deeply of what they had been presented with and that it was just a regular class. When it came to the second question, most of them mentioned that it helped them understand the tenses and their use better. However, the last exercise did not confirm their statements. Some of them answered that they liked the role play and construction of their own sentences. Regarding the third question, the average answer amounted to 2.5 with the majority of them answering with 2 or 3 . In other words, they perceived it as a regular class and not different in any way. Very similar answers were provided in the fourth question as well. The average number was 3.2, which again indicated that the students did not 
particularly enjoy the class or find it engaging enough. The majority of them answered with 3 . The fifth question proved to be the most challenging one for them since some of them provided no answer, whereas a few of them wrote a sentence or two. This indicated that the examples done at class were distinct or memorable by no means. A decontextualized learning environment proved to be disadvantageous. In the sixth question, $60 \%$ of students answered role play and the last exercise. This suggested that they perceived acting and comparing the tenses as entertaining and useful for their mastery of the units, although these were rare instances that made the class different than usual.

Table 1. The comparison of the control and experimental group in accuracy (\%)

\begin{tabular}{lll}
\hline Exercise number & Success of c. g. & Success of e. $g$. \\
\hline 1. & 90 & 90 \\
\hline 2. & 84 & 80 \\
\hline 3. & 86 & 81 \\
\hline 4. & 67 & 85 \\
\hline
\end{tabular}

Table 2. The comparison of the control and experimental group in their agreement with certain statements from the questionnaire (the average value out of 5) - only answers 4 and 5 were considered

\begin{tabular}{|c|c|c|}
\hline Question number & $\begin{array}{ll}\text { Agreement } & \text { with } \\
\text { statement (c.g.) }\end{array}$ & $\begin{array}{l}\text { Agreement } \\
\text { statement (e.g.) }\end{array}$ \\
\hline 1. & 3 & 4.7 \\
\hline 3. & 2.5 & 4.5 \\
\hline 4. & 3.2 & 4.5 \\
\hline
\end{tabular}

Test (experimental group)

For the first question, the majority of the students provided $90 \%$ of correct answers about the use (Table 1), which proved to be identical to the control group. The students did not have too many options to choose from, so 
not too many mistakes were expected. A benefit of their class was the focus on the uses, which could additionally play a role in achieving a high score.

The second question was done very well (80\%), with a slightly lower accuracy rate than in the control group. An interpretation of the results could be that they scored worse than the control group because the focus of their class was on situations rather than on the form. Bearing this in mind, the score was still very high. This seemed to be the first step where the contextualized approach showed its minor disadvantages.

The same could be said about the third question. The result was again very high $(81 \%)$, but not as high as in the control group. The distinction between have and has was somewhat of a problem, while a significant number of them used the Past Participle instead of the Present Participle. Some students omitted the Past Participle been. These mistakes suggested that the modern approach did not deal with all types of exercises more efficiently than the traditional one.

The fourth question proved to be the easiest one (85\%), especially comparing it to the control group. This implied that choosing the correct tense was the easier task for them due to their exposure to whole situations they could relate to. Since these situations involved characters whom the students liked and plots they were deeply engaged in, they were more likely to understand the tenses and what the reason was for choosing them. They were able to remember a number of sentences uttered by the heroes and apply them in new sentences. They seemed to have mastered the essence of the tenses as opposed to the formation, although this aspect of their knowledge did not suffer greatly, especially in this exercise. A type of the exercise where they would have excelled would have been a multiple choice exercise 
because they would have had to simply choose one of the provided tenses, based on the meaning.

In the questionnaire, the results were significantly different with reference to the control group. In the first question, the students provided answer 5 in $80 \%$ of the cases, making that a total average of 4.7 (Table 2). The vast majority of them clearly enjoyed this format of the class due to its entertaining nature. In the second question, they mostly stated that they particularly liked discussing grammar in a completely different way, by actually watching movie clips at class. Naturally, $90 \%$ of them answered that it was a special class presumably because they did not have the chance to watch their favourite superheroes at class that often, with nine of them circling 5 on the scale. It should not surprise us that $90 \%$ of them also provided answers 4 and 5 for the fourth question. Playing videos of movies that they had watched proved to be essential in boosting their motivation and enthusiasm to cooperate. In the fifth question, the number of examples they provided was visibly higher than in the control group. Although there were occasional mistakes, the number of the answers they provided ranged from 3 to 6. Teaching through popular culture obviously facilitated the process of remembering almost complete sentences in their entirety. The answers for the sixth question were very diverse. This, again, suggested that they perceived different exercises as crucial simply because all of them had to do with analysing the content uttered by the superheroes from the movies.

\section{CONCLUSION}

Having considered the findings from both the control and experimental group, the results were slightly in favour of the control group 
when doing the exercises that were related to the form of the tenses. However, the results in the exercise where they had to choose the correct tense showed that the experimental group had the upper hand in making the right choice. When it came to their perception of which class they found more appealing, they were highly in favour of the experimental one. Being exposed to the content they could relate to was a key factor in making their choice. They were highly motivated and considered the class special compared to some other classes they had had. They were also able to recall a number of examples from the class, which essentially facilitated the learning process. Therefore, studying grammar through popular culture which is naturally more suited for the functional top-down approach of teaching has its obvious advantages. For the purpose of making the experimental class even more complete, it would be advisable to introduce the discussion about the form as a supplement to learning the use. In other words, an additional effort should be made at the end of the class to emphasise the formation of different tenses as opposed to letting the students to conclude this on their own.

\section{PREDAVANJE ENGLESKIH GLAGOLSKIH VREMENA KROZ UPOTREBU POPULARNIH FILMOVA - STUDIJA SLUČAJA}

\section{Apstrakt}

Rad se bavi predavanjem engleskih glagolskih vremena Present Perfect i Present Perfect Continuous upotrebom scenarija i inserata iz popularne filmske sage Osvetnici. Značaj teme ogleda se u tome što učenici često doživljavaju gramatiku kao najteži i najdosadniji aspekat savladavanja jezika. Međutim, ukoliko se ona predaje $\mathrm{u}$ nešto izmenjenom obliku u odnosu na ono što uglavnom zatičemo $\mathrm{u}$ učionici, može se promeniti stav prema ovoj problematici. Udžbenici imaju tendenciju da gramatiku predstavljaju odozdo prema gore (bottom-up) tj. sa 
primarnim fokusom na građenje i pravila, gde je upotreba sekundarna $\mathrm{i}$ data $\mathrm{u}$ kontekstu koji je često neprilagođen polaznicima. Korišćenjem pristupa odozgo prema dole (top-down), gde je fokus na značenju i upotrebi vremena datih u okviru filmskih scenarija propraćenih insertima iz filmova, može se očekivati veći nivo zainteresovanosti učenika za čas. Cilj rada je upravo da pokaže da li eksperimentalna grupa podvrgnuta ovakvom pristupu može da pokaže dobre rezultate, kako po pitanju savladavanja gramatičkih jedinica tako i po pitanju podizanja nivoa motivacije kod polaznika. Primenjeni metod u istraživanju je eksperimentalan sa paralelnim grupama, uz deskriptivnu analizu i statističku obradu dobijenih podataka i primenu tehnike testiranja. Rezultati istraživanja pokazali su da je kontrolna grupa (B1 nivo), koja je bila podvrgnuta tradicionalnom pristupu sa fokusom na obliku glagolskih jedinica bila nešto bolja od eksperimentalne grupe upravo kod zadataka gde je akcenat bio na tačnosti u pogledu građenja vremena. Međutim, u zadatku gde je trebalo ustanoviti koje vreme treba da se primeni, eksperimentalna grupa ostvarila je bolje rezultate. Upitnik u okviru testa koji su obe grupe popunile pokazao je da su polaznici eksperimentalne grupe bili mnogo motivisaniji za čas jer im se svideo format u kojem im je predstavljen sadržaj. Imajući u vidu ovakve rezultate, trebalo bi sistematski uvoditi opisani pristup u predavanje gramatičkih jedinica i pretvoriti nastavnu jedinicu koja je teška i nezanimljiva u onu koju su učenici voljni da rade. Kako bi rezultati bili što bolji, predlaže se kombinovanje modernijeg pristupa sa tradicionalnijim u pogledu savladavanja građenja vremena.

Ključne reči: popularna kultura, motivacija, pristup odozgo prema dole, funkcionalni gramatički pristup. 


\section{REFERENCES}

Brown, S. K. (2010). Popular films in the EFL classroom: Study of methodology. Procedia Social and Behavioral Sciences, 3, 45-54.

Byrd, P. (2005). Instructed Grammar. In: E. Hinkel (ed.), Handbook of Research in Second Language Teaching and Learning, (pp. 545-563). New Jersey: Lawrence Erlbaum Associates.

Cheung, C. (2001). The use of popular culture as a stimulus to motivate secondary students' English learning in Hong Kong. ELT Journal Volume, 55, 55-61.

Gale, J. (2012). Japanese Popular Culture as a Major Motivation for Japanese Language Study. California: San Francisco State University. Harmer, J. (1991). The Practice of English Language Teaching. New York: Longman Publishing.

Henderson, X. (2017). An Investigation of Metacognitive, Botom-up and Top-down Strategies in L2 Listening. Monterey Bay: Capstone Projects and Master's Theses.

Hyte, H. (2016). Bottom-Up and Top-Down Strategies (or Processing): What Are They Anyway? Accessed 25 May 2019 from http://www.esltrail.com/2016/06/bottom-up-and-top-down-strategiesor.html.

Ismaili, M. (2013). The Effectiveness of Using Movies in the EFL Classroom -A Study Conducted at South East European University. Academic Journal of Interdisciplinary Studies, 4, 121-132.

Jean, G., \& Simard, D. (2011). Grammar Teaching and Learning in L2: Necessary, but Boring? Foreign Language Annals, 44, 467-494.

Kalra, R. (2017). The Effectiveness of Using Films in the EFL Classroom: A Case Study Conducted at an International University in Thailand. Arab World English Journal (AWEJ), 8, 289-301.

Khan, A. (2015). Using films in the ESL classroom to improve communication skills of non-native learners. ELT Voices, 5, 46-52.

Kim, J. (2007). A comparative study of the effects of explicitinductive/cooperative instruction versus explicit-deductivel individualistic instruction on the second language acquisition of 
English relative clauses in Korean university-level EFL learners. Michigan: ProQuest Dissertations and Theses.

Kinet, A., \& Meunier, F. (2018). The impact of grammar teaching methods on EFL pupils' achievement and motivation: traditional vs. technology-enhanced. Louvain: FIAL.

Long, M. H., \& Doughty, C. J. (2009). The Handbook of Language Teaching. Malde: Wiley Blackwell.

Male, H. (2018). Understanding inductive and deductive approaches in teaching grammar in efl context. $J D P, 9,19-24$.

Ozkan, Y. (2015). Utilization of news articles in English grammar teaching. Haziran, 17, 49-59.

Statista (2019). Cinema audience distribution in the United Kingdom (UK) as of 2014, by age and gender. Accessed 18 August 2019 from https://www.statista.com/statistics/296240/age-and-gender-of-thecinema-audience-uk/.

Using English (2019). Top-down Language Learning. Accessed 26 May 2019 from https://www.usingenglish.com/glossary/top-down.html.

Weebly (2019). Teaching Grammar for Middle and Upper Primary Years. Accessed 26 May 2019 from

https://teachinggrammartoupperandmiddleprimary.weebly.com/traditi onal-vs-functional-grammar.html.

Winch, G. (2010). Literacy: Reading, Writing and Children's Literature. South Melbourne: Oxford University Press. 


\section{APPENDIX}

Test

1. Which of the 2 tenses refer to:

a) a finished event or events?

b) an activity that may not be finished?

c) an activity continuing or repeated over a period of time?

2. Complete the sentences using the Present Perfect tense.

a) (you / eat Thai food before)?

b) (we / not / hear that song yet)

c) (he / not / forget his books)

d) (he / not hurt his leg)

e) (she / leave her phone in a taxi)

f) (she / call her mother)?

g) Help, I (lose) my wallet. How can I get home?

h) (he / not / forget his books)

i) (who / we / forget to invite)?

j) (who / he / meet recently)?

3. Complete the sentences using the Present Perfect Continuous tense.

a) I (read) your book all day. It's very interesting, but I'm only on chapter 2 .

b) (it/rain all day)?

c) They (not study) very hard recently.

d) She (take) French lessons lately.

e) It (not rain) for three hours! Only about one hour.

f) I (call) John for hours and hours and he hasn't answered. I'm really angry with him! 

g) She (eat) chocolate all morning, so she feels sick.
h) I (paint) my house all day, but it's not finished yet.
i) I (drink) more water recently, and I feel better.
j) how long (rain)?

4. Complete the sentences using the Present Perfect or Present Perfect Continuous
a) (they/arrive) already?
b) Lucy (run) 2000 metres today.
c) I (clean) all morning - I'm fed up!
d) How many times (you/take) this exam?
e) He (eat) six bars of chocolate today.
f) Julie (cook) dinner. Let's go and eat!
g) Iona is exhausted these days. She (work) too hard recently.
h) I (wait) three hours already!
i) (you/finish) your homework yet?
j) She (drink) ten glasses of water! 


\section{Questionnaire}

Write numbers 1 (weakest agreement) to 5 (strongest agreement) next to the statements. Answer the questions as well.

1) I found this class interesting.

2) If you liked this class, what in particular did you like?

3) This was a special class.

4) I was motivated at class more than usually.

5) Which examples do you remember from the class?

6) Which exercise helped me understand how to use the tenses the most? 